преодоление препятствий, решение трудных задач. Человек ориентирован на то, чтобы бросать вызов. Новизна, разнообразие и вызов имеют для людей с такой ориентацией очень большую ценность, и, если всё идет слишком просто, им становится скучно.

Предпринимательство и положительная мотивация $($ Rэмп $=0,5)$. По результатам исследования можно сделать вывод о том, что человек с такой ценностной ориентацией стремится создавать что-то новое, он хочет преодолевать препятствия, готов к риску. Он не желает работать на других, а хочет иметь свою марку, своё дело, своё финансовое богатство. Для него главное создать дело, концепцию или организацию, построить ее так, чтобы это было продолжением его самого, вложить туда душу. Как правило, такой человек готов идти на риски.

Таким образом, по итогам проведенного исследования у представителей политической деятельности, была выявлена значимая взаимосвязь между ценностными ориентациями и профессиональной мотивацией. У представителей политической деятельности ведущими ориентациями являются такие, как профессиональная компетентность и служение народу, взаимосвязанное с внутренними социально значимыми мотивами.

Результаты проведенного исследования позволяют узнать больше информации о психологических особенностях представителей политической деятельности и их истинных мотивах выбора политической деятельности. А также теоретические и эмпирические данные исследования могут быть полезны в последующих научных работах по данной теме, поскольку в наше время она мало изучена и является актуальной для современного общества.

$$
* * *
$$

1. Веснин, В.Р.Практический менеджмент персонала [Текст]: Пособие по кадровой работе / В. Р. Веснин. - Москва: Юристь, 2015. - 496 с.

2. Домашев. Е. В. Карманный справочник по обществознанию [Текст] / Е. В. Домашев. Ростов-наДону: Феникс. 2015. - 238c.

3. Здравомыслов, А. Г. Человек и его работа в СССР и после [Текст]: Учебное пособие для вузов / А. Г. Здравомыслов., В. А. Ядов - 2-е изд., испр. и доп. - Москва: Аспект Пресс, 2003. - 485 с.

4. Касьянов, В. В. Обществознание [Текст]: учебное пособие для студентов средних специальных учреждений / В. В. Касьянов. - 3-е изд. - Ростов-на-Дону: Феникс, 2017. - 416 с.

5. Ольшанский, Д. В. Основы политической психологии. [Текст] / Д. В. Ольшанский. - Екатеринбург: Деловая книга, 2001. - 496 с.Психология политической деятельности [Электронный ресурс]. Режим доступа: http://azps.ru/polpsy/lib/theory_doings.html. Дата обращения: 01.12.2017.

6. Шестопал, Е. Б. Политическая психология [Текст]: Учебник для вузов / Е. Б. Шестопал - Москва: ИНФРА-М, 2011. - 448 c.

7. Шиляева, Л. Б. К вопросу изучения ценностных ориентаций как составляющей жизненной перспективы личности [Электронный ресурс] // Л. Б. Шиляева. Международный журнал экспериментального образования. - 2014. - № 6-1. - С. 2628;Режим доступа:https://www.expeducation.ru/ru/article/view?id=4922. Дата обращения:01.12.2017.

Годовникова Л.В.

Актуальные проблемы комплексного сопровождения обучающихся с ОВЗ в условиях образовательной инклюзии

Белгородский государственный национальный исследовательский университет (Россия, Белгород)

doi 10.18411/spc-04-03-2018-22

idsp 000001:spc-04-03-2018-22

Наиболее приоритетным и закономерным направлением модернизации современного общего и специального образования в изменяющейся России выступает инклюзивное образование. Инклюзивное (включённое) образование подразумевает 
обучение и воспитание в одном классе детей с разными особенностями развития при обеспечении поддержки всем, кто в ней нуждается.

В связи с введением с 1 сентября 2016 года Федерального государственного образовательного стандарта начального общего образования обучающихся с ограниченными возможностями здоровья (ФГОС НОО ОВЗ) и Федерального государственного образовательного стандарта образования обучающихся с умственной отсталостью (интеллектуальными нарушениями) (ФГОС УО) вопрос организации комплексного сопровождения инклюзивного образования детей с ОВ3 особенно актуален.

Специалисты психолого-педагогического сопровождения, работающие в современных общеобразовательных организациях, должны быть готовы к решению такой важной задачи, как осуществление коррекционной помощи обучающимся с ограниченными возможностями здоровья.И эта категория учащихся с каждым годом становится всё более многочисленной.

Качественное психолого-педагогическое сопровождение субъектов образовательной деятельности в условиях инклюзивного образования возможно только при условии наличия необходимых кадровых условий, а в команде специалистов сопровождения одно из ведущих мест принадлежит педагогу-психологу.

К сожалению, пока система высшего профессионального образования не готовит достаточное количество специалистов психолого-педагогического сопровождения инклюзивного образования. Российские образовательные организации испытывают дефицит педагогов-психологов и других специалистов психолого-педагогического сопровождения. С другой стороны, содержание программ высшего профессионального образования требуют совершенствования в плане подготовки специалистов для инклюзивного образования.

В целях модернизации психологической службы образования в Российской Федерации был разработан профессиональный стандарт «Педагог-психолог (психолог в сфере образования)», который должен выступать ориентиром для работодателей и системы подготовки специалистов. Профстандарт «Педагог-психолог (психолог в сфере образования)» включает в себя две обобщенные трудовые функции: «Психологопедагогическое сопровождение образовательного процесса в образовательных организациях общего, профессионального и дополнительного образования, сопровождение основных и дополнительных образовательных программ» (обобщённая трудовая функция А) и «Оказание психолого-педагогической помощи лицам с ограниченными возможностями здоровья, испытывающим трудности в освоении основных общеобразовательных программ, развитии и социальной адаптации, в том числе несовершеннолетним обучающимся, признанным в случаях и в порядке, которые предусмотрены уголовно-процессуальным законодательством, подозреваемыми, обвиняемыми илиподсудимыми по уголовному делу либо являющимся потерпевшими или свидетелями преступления» (обобщённая трудовая функция В).

Обобщенная трудовая функция «Оказание психолого-педагогической помощи лицам с ограниченными возможностями здоровья...» (код $\mathrm{B}$ ), имеющая непосредственное отношение к работе педагога-психолога с детьми с ОВ3, включает в себя следующие трудовые функции:

- Психологическое просвещение субъектов образовательного процесса в области работы по поддержке лиц с ограниченными возможностями здоровья, детей и обучающихся, испытывающих трудности в освоении основных общеобразовательных программ (ООП), развитии и социальной адаптации.

- Психологическая профилактика нарушений поведения и отклонений в развитии лиц с ограниченными возможностями здоровья, детей и 
обучающихся, испытывающих трудности в освоении ООП, развитии и социальной адаптации.

- Психологическое консультирование лиц с ограниченными возможностями здоровья и обучающихся, испытывающих трудности в освоении ООП, развитии и социальной адаптации.

- Психологическая коррекция поведения и развития детей и обучающихся с ограниченными возможностями здоровья, а также обучающихся, испытывающих трудности в освоении ООП, развитии и социальной адаптации.

- Психологическая диагностика особенностей лиц с ограниченными возможностями здоровья, обучающихся, испытывающих трудности в освоении ООП, развитии и социальной адаптации[1].

Каждая из перечисленных выше трудовых функций B/01/7 - B/05/7 профстандарта «Педагог-психолог (психолог в сфере образования)» требует от специалиста высокого уровня подготовки в области специальной психологии и инклюзивного образования.

Таким образом, эффективность комплексного сопровождения обучающихся с OB3 в условиях образовательной инклюзии зависит от готовности специалистов сопровождения, и, в первую очередь, педагогов-психологов, к реализации командной работы по всем направлениям деятельности, обозначенным в профессиональном стандарте «Педагог-психолог (психолог в сфере образования)».

$$
* * *
$$

1. Профессиональный стандарт «Педагог-психолог (психолог в сфере образования)». URL: http://rospsy.ru/node/1878 (дата обращения: 06.05.2017).

\section{Кудряшова Е.А. \\ Особенности эмоционального состояния в младшем и старшем подростковом возрасте}

Новокузнецкий институт (филиал) ФГБОУ ВО «Кемеровский государственный университет» (Россия, Новокузнеик)

doi 10.18411/spc-04-03-2018-23

idsp 000001:spc-04-03-2018-23

На протяжении многовековой истории исследования эмоций они пользовались самым пристальным вниманием, им отводилась одна из центральных ролей среди сил, определяющих внутреннюю жизнь и поступки человека.

Большое значение проблемы эмоций обосновывается тем, что вне зависимости от условий и детерминант, определяющих жизнь и деятельность человека, психологически действенными они становятся лишь в том случае, если им удается проникнуть в сферу его эмоциональных отношений и закрепиться в ней. Конституируя в человеке пристрастность и субъективность, эмоции значительно влияют на познание и искусство, творчество и душевные кризисы человека.

Изучение эмоционального развития подростков занимает ведущее место в психологии, потому как подростковый возраст считается особенно «эмоционально насыщенным».

Несмотря на то, что работы 3. Фрейда и У. Макдугала заложили фундамент для изучения эмоций и эмоциональных различий, одна из наиболее серьёзных проблем в психологии заключается в том, что большинство авторов так и не пришли к общему мнению, что такое эмоции и не определили подход к их изучениям [5]. 